\title{
Runx3 Expression and Its Roles in Mouse Endometrial Cells
}

\author{
Yukiko TSUCHIYA ${ }^{1)}$, Yuka SAITO ${ }^{1}$, , Shusuke TANIUCHI ${ }^{1)}$, Atsuko SAKUMA ${ }^{1}$, \\ Tetsuya MAEKAWA ${ }^{1}$, Hiroshi FUKAMACHI ${ }^{2}$, Sakae TAKEUCHI' ${ }^{1}$ and Sumio TAKAHASHI ${ }^{1)}$ \\ 1) Graduate School of Natural Science and Technology, Okayama University, Okayama 700-8530, Japan \\ 2) Graduate School of Medicine and Dentistry, Tokyo Medical and Dental University, Tokyo 113-8519, Japan
}

\begin{abstract}
Runx3 is a transcription factor that belongs to the Runx family. We studied the localization of Runx $3 \mathrm{mRNA}$ in the mouse uterus, and its function in the mouse endometrium using Runx3 knockout $\left(\right.$ Run $\left.x 3^{--}\right)$mice. Run $x 3$ mRNA was detected in the endometrial luminal epithelial cells, glandular epithelial cells and stromal cells below the epithelial cell layer on the luminal side. The uteri of Runx $3^{-/-}$mice were smaller than those of wt mice. The endometrial layer and uterine glands of Run $\times 3^{-/}$mice were less developed than those of wild-type mice, and the endometrial stromal layer was thinner. Transforming growth factor $\beta 1$ and $\beta 3$ (TGF $\beta 1$ and $\beta 3$ ) mRNA levels in endometrial stromal cells of $R u n \times 3^{3^{--}}$mice were low compared with those of wild-type mice. Estradiol-17 (E2) increased $T g f b 2 \mathrm{mRNA}$ levels in endometrial stromal cells of Runx $3^{-/-}$mice, but not in those of wild-type mice. E2 increased epidermal growth factor (EGF) mRNA levels in endometrial stromal cells of wild-type mice, but did not increase those of $R u n x 3^{-/-}$mice. The diminished $T g f b 1$ and $T g f b 3 \mathrm{mRNA}$ expressions may lead to the reduced proliferation of endometrial stromal cells. Alterations of E2-associated expressions of $T g f b 2$ and $E g f$ mRNA in endometrial stromal cells of Runx $3^{-/}$mice may be associated with suppression of E2-dependent endometrial epithelial cell proliferation in Runx $3^{-/-}$mice. Thus, Runx3 is likely to be a regulatory factor responsible for endometrial growth.
\end{abstract}

Key words: Estrogen, Growth factor, Mouse, Runx3, Uterus

(J. Reprod. Dev. 58: 592-598, 2012)

$\mathbf{T}$ he mammalian protein runt-related transcription factor 3 (Runx3) belongs to a family of runt domain transcription factors and is also called the polyomavirus enhancer binding protein 2(PEBP2)/core binding factor (CBF). PEBP2 is heterodimeric complex composed of $\alpha$ and $\beta$ subunits [1]. The $\alpha$ subunit-encoding gene is homologous to the Drosophila gene runt, and the encoded protein contains a conserved Runt domain, which is required for dimerization with the $\beta$ subunit and binds with the consensus DNA sequence. Three runt-related genes, Runx1, Runx2 and Runx3, have been identified in mammals. These Runx members interact with Smad 2 or Smad3, and are involved in transforming growth factor $\beta$ (TGF $\beta$ ) superfamily signaling [2].

Endometrial epithelial cell proliferation is induced by estradiol-17 $\beta$ (E2), while proliferation of endometrial stromal cells is induced by the combination of estrogen and progesterone [3]. The uterus of Run $x 3^{--1}$ mice is atrophic, and the endometrial layer is less developed than that of wild-type (wt) mice. E2-induced endometrial epithelial cell proliferation is not detected in Runx $3^{--}$mice [4]. Therefore, Runx3 may be involved in the regulation of E2-induced endometrial cell proliferation. Endometrial cell proliferation is regulated by growth factors produced in the uterus [5-7]. Insulin-like growth factor-1 (IGF1), and epidermal growth factor (EGF) family member, EGF and transforming growth factor- $\alpha$ (TGF $\alpha$ ), are well known to stimulate proliferation of endometrial epithelial and stromal cells

Received: April 6, 2012

Accepted: May 28, 2012

Published online in J-STAGE: June 29, 2012

(C)2012 by the Society for Reproduction and Development

Correspondence: S Takahashi (e-mail: stakaha@cc.okayama-u.ac.jp)
[8-13]. TGF $\beta$ family members are also involved in the regulation of proliferation of endometrial cells $[6,14]$. It is probable that Runx3 may play roles in the regulation of growth factor production.

In the present study, we aimed to know Runx 3 mRNA expression in the mouse uterus, and the mechanism by which E2-induced endometrial cell proliferation does not occur in Runx $3^{-1-}$ mice. We analyzed Runx 3 mRNA expression in uteri by in situ hybridization. To investigate endometrial proliferation in $R u n x 3^{-/-}$mice, we used a primary endometrial epithelial and stromal cell culture system. We studied the mRNA expressions of the estrogen receptor $\alpha(\mathrm{ER} \alpha)$ gene $(E s r l)$ and growth factors regulating endometrial cell proliferation (IGF1, EGF, TGF $\alpha$, TGF $\beta 1$, TGF $\beta 2$ and TGF $\beta 3$ ).

\section{Materials and Methods}

\section{Animals}

Runx 3 knockout $\left(\right.$ Run $^{3^{--}}{ }^{-}$) mice on a BALB/c genetic background were generated as described previously [15]. The animals were kept in a temperature-controlled animal room, and were fed CA-1 (CLEA Japan, Tokyo, Japan), and tap water ad libitum. All animal care and experimental procedures were performed in accordance with Guidelines for the Animal Experimentation of Okayama University, Japan.

\section{Genotyping}

Heterozygous mice $\left(\right.$ Run $\left.x 3^{+/-}\right)$were intercrossed. The offsprings were genotyped as described previously [16]. Polymerase chain reaction (PCR) was performed using Blend Taq (Toyobo, Osaka, Japan) and the following primers: 1) 5'-GAC TGT GCA TGC ACC TTTCAC CAA-3', 2) 5'-ATGAAACGCCGAGTTAACGCCATCA-3' 
and 3) 5'-TAGGGCTCAGTAGCACTTACGTCG-3'. The conditions comprised a denaturation step at $95 \mathrm{C}$ for $5 \mathrm{~min}$; 12 cycles at $95 \mathrm{C}$ for $35 \mathrm{sec}, 58 \mathrm{C}$ for $30 \mathrm{sec}, 72 \mathrm{C}$ for $45 \mathrm{sec}$; 25 cycles at $95 \mathrm{C}$ for $35 \mathrm{sec}, 64 \mathrm{C}$ for $45 \mathrm{sec}, 72 \mathrm{C}$ for $45 \mathrm{sec}$; and then a final extension step at $72 \mathrm{C}$ for $10 \mathrm{~min}$. PCR products were electrophoresed on $2.0 \%$ agarose gels, and stained with ethidium bromide. The presence of a 170-base pair (bp) band indicated that the mice were wt. The presence of a 550-bp fragment indicated that the mice were homozygous for the Runx 3 deletion, whereas the presence of both the 170- and $550-\mathrm{bp}$ bands indicated that the mice were heterozygous for the Runx3 deletion.

\section{Endometrial epithelial and stromal cell isolation}

Endometrial epithelial and stromal cells were isolated from 3-week-old wt mice and 9-week-old $R u n x 3^{-/-}$mice for culture, and from 8 week-old wt and Run $x 3^{--}$mice for RNA extraction according to a previously described method of Ross et al. [17]. Briefly, the uteri were dissected, and the uterine horns were longitudinally cut to expose the endometrial luminal surface. The tissue fragments were treated with $0.1 \%$ trypsin (Sigma-Aldrich, St. Louis, MO, USA) at $4 \mathrm{C}$ for $1 \mathrm{~h}$ and then at $37 \mathrm{C}$ for $55 \mathrm{~min}$. Trypsin was inactivated by $0.1 \%$ soybean trypsin inhibitor (STI, Sigma-Aldrich) at $37 \mathrm{C}$ for $10 \mathrm{~min}$. The epithelial tissues were separated from the stromal tissues with forceps under a stereoscopic microscope. The collected epithelial tissue fragments were further divided into smaller fragments by gentle pipetting. The endometrial stromal and myometrial tissues separated from the epithelial tissues were incubated with $0.1 \%$ trypsin and $1 \mathrm{mM}$ EDTA at $37 \mathrm{C}$ for $1 \mathrm{~h}$. Then they were treated with $0.1 \%$ STI at $37 \mathrm{C}$ for $10 \mathrm{~min}$. After gentle pipetting and DNase I (Sigma-Aldrich) treatment, the stromal cells separated from the myometrium were collected by centrifugation. The cell viability was assessed by the trypan blue dye exclusion test (usually more than $95 \%$ in each study). The purities of the epithelial and stromal cells were more than $90 \%$, as verified by our previously described method $[8,13]$. All chemicals were dissolved in $\mathrm{Ca}^{2+}$ - and $\mathrm{Mg}^{2+}$-free Hanks' solution containing $20 \mathrm{mM}$ HEPES and $0.3 \%$ bovine serum albumin (BSA, Sigma-Aldrich).

\section{Endometrial epithelial and stromal cell culture}

The isolated endometrial epithelial and stromal cells were seeded on poly-L-lysine-coated culture wells at a density of approximately $5 \times 10^{4}$ or $6 \times 10^{4}$ cells $/ \mathrm{cm}^{2}$, respectively. Stromal cells were first cultured for 1 day in a 1:1 mixture of Dulbecco's modified Eagle's medium and Ham's F12 medium without phenol red (DME/F12; Sigma-Aldrich) containing 2\% dextran-coated charcoal-treated fetal bovine serum for 1 day. After the 1-day pre-culture, the cells were cultured in serum-free DME/F12 supplemented with BSA (1 g/l), hydrocortisone $(100 \mu \mathrm{g} / \mathrm{l})$, triiodothyronine (400 $\mathrm{ng} / \mathrm{l})$, transferrin (10 mg/l), glucagon (10 ng/l), parathormone (200 ng/l), sodium selenite $(5 \mu \mathrm{g} / \mathrm{l})$ and insulin $(100 \mu \mathrm{g} / \mathrm{l})$. The plates were incubated at $37 \mathrm{C}$ in an atmosphere of a $5 \% \mathrm{CO}_{2}$.

E2 (Sigma-Aldrich) was initially dissolved in ethanol to yield a $10 \mu \mathrm{M}$ stock solutions $(0.03 \%$ ethanol, $)$. The stock solution was diluted with culture medium, and the final ethanol concentration was less than $0.01 \%$.

\section{RNA extraction and reverse transcription (RT)}

Total RNA was extracted using TRIsure reagent (BIOLINE, London, UK). Five hundred nanograms of RNA were used for RT using the ThermoScript RT-PCR System (Invitrogen, Carlsbad, CA, USA) according to the manufacturer's instructions. Random hexamers were used for the RT reactions.

\section{RT-PCR}

PCR was carried out in a $15-\mu 1$ final volume containing the following reagents: autoclaved water up to $15 \mu 1,0.375 \mathrm{U}$ of Blend Taq (Toyobo), $1 \times$ PCR Buffer for Blend Taq, $0.2 \mu \mathrm{M}$ each of forward and reverse primer and $1.2 \mu \mathrm{l}$ of 1:8 diluted cDNA. For Runx3 RT-PCR, $0.5 \mu \mathrm{M}$ of each primer was used. PCR reactions were performed using a Gene Amp PCR System 9700 thermal cycler (Applied Biosystems, Foster City, CA, USA). The PCR conditions were 30 $\mathrm{sec}$ at $94 \mathrm{C}$; an appropriate number of cycles of $94 \mathrm{C}$ for $30 \mathrm{sec}$, a primer-appropriate temperature for $30 \mathrm{sec}$ and $72 \mathrm{C}$ for $30 \mathrm{sec}$; and finally $10 \mathrm{~min}$ at $72 \mathrm{C}$. The primers and PCR conditions are listed in Table 1. A 10- $\mu$ l aliquot of each reaction was electrophoresed on $2 \%$ agarose gel, stained with ethidium bromide, and photographed under ultraviolet light.

\section{Western blotting}

The uteri and ovaries of 8 -week-old wt mice were frozen and homogenized in cold lysis buffer (50 mM Tris- $\mathrm{HCl}(\mathrm{pH} 7.5), 250$ $\mathrm{mM} \mathrm{NaCl}, 0.1 \%$ Nonidet P-40, 2 mM EDTA (pH 8.0), 10\% glycerol) containing $1 \%$ protease inhibitor cocktail (Sigma-Aldrich). After sonication, protein lysates were separated by centrifugation. Lysates containing $80 \mu \mathrm{g}$ of protein were subjected to $8 \%$ SDS-polyacrylamide gel electrophoresis and transferred to a nitrocellulose membrane (Schleicher \& Schuell, Keene, NH, USA). The membranes were blocked for $1 \mathrm{~h}$ with $10 \%$ skim milk dissolved in Tris-buffered saline containing $0.1 \%$ Tween-20 (TBS-T). Then the membranes were incubated sequentially with $0.2 \mu \mathrm{g} / \mathrm{ml}$ mouse anti-Runx3 antibody (R3-1E10; Medical \& Biological Laboratories, Nagoya, Japan) diluted with phosphate-buffered saline (PBS, pH 7.2) and with EnVision+ Dual Link rabbit/mouse (1:50, Dako, Glostrup, Denmark) diluted with TBS-T containing $1 \%$ skim milk, each for $1 \mathrm{~h}$ at room temperature. Peroxidase activity was detected by using luminol (Sigma-Aldrich) and a hydrogen peroxide reaction. $\beta$-actin was used as an internal control, and was detected using anti- $\beta$-actin antibody (GeneTex, Irvine, CA, USA).

\section{Riboprobes}

A mouse Runx3 riboprobe was generated from a Runx3 fragment (NM_019732: nucleotides 1244-2344) subcloned into pBluescript II $\mathrm{KS}(-\overline{)}$, according to a previously described method [18]. The plasmid DNA was linearized using restriction enzymes, and RNA probes were synthesized using a T3 and T7 polymerase system (Promega, Madison, WI, USA) according to the manufacturer's instructions. The probe was labeled with digoxigenin (DIG; Roche Diagnostics, Mannheim, Germany).

\section{In situ hybridization analysis}

The dissected uteri of 8 -week-old wt mice were immediately embedded in O.C.T. Compound (Sakura Finetek Japan, Tokyo, Japan) 
Table 1. PCR primer sequences

\begin{tabular}{|c|c|c|c|}
\hline Target gene & & Sequence & Length \\
\hline \multirow[t]{2}{*}{ Runx3 } & FP & AAGTGCGCTCGATGGTGGACG & 369 \\
\hline & $\mathrm{RP}$ & CAGTGACCTTGATGGCTCGGT & \\
\hline \multirow[t]{2}{*}{ Krt19 } & FP & GTGTCTGATGGGCTGCTGTCT & 539 \\
\hline & $\mathrm{RP}$ & CTCAGGATCTTGGCTAGGTCG & \\
\hline \multirow[t]{2}{*}{$\operatorname{Vim}$} & FP & GGCCGAGGAATGGTACAAGTC & 320 \\
\hline & $\mathrm{RP}$ & GGGCCATCTTAACATTGAGCAG & \\
\hline \multirow[t]{2}{*}{ Esrl } & FP & GGCTGGAGATTCTGATGATTGG & 55 \\
\hline & $\mathrm{RP}$ & TTCCCCGGGTGTTCCAT & \\
\hline \multirow[t]{2}{*}{$\operatorname{Igfl}$} & FP & AAAGCAGCCCGCTCTATCC & 57 \\
\hline & $\mathrm{RP}$ & CTTCTGAGTCTTGGGCATGTCA & \\
\hline \multirow[t]{2}{*}{$\operatorname{Igfbp} 3$} & FP & AAGCACCTACCTCCССТCCCAA & 98 \\
\hline & $\mathrm{RP}$ & TGCTGGGGACAACCTGGCTTTC & \\
\hline \multirow[t]{2}{*}{$E g f$} & FP & CTACGGGCAGAAGCATGACA & 97 \\
\hline & $\mathrm{RP}$ & CCTGTAGTAGTAAGTCCCCCACATC & \\
\hline \multirow[t]{2}{*}{$T g f a$} & FP & ATCCTGTTAGCTGTGTGCCA & 105 \\
\hline & $\mathrm{RP}$ & GGAATCTGGGCACTTGTTGA & \\
\hline \multirow[t]{2}{*}{$T g f b l$} & FP & CTGGAGTTGTACGGCAGTG & 98 \\
\hline & $\mathrm{RP}$ & GTGGAGTTTGTTATCTTTGCTG & \\
\hline \multirow[t]{2}{*}{$\operatorname{Tg} f b 2$} & FP & GCTTGCAAAACCCCAAAGC & 90 \\
\hline & $\mathrm{RP}$ & GCTGGGTGGGAGATGTTAAGTCT & \\
\hline \multirow[t]{2}{*}{$T g f b 3$} & FP & GATCCATAAATTCGACATGATCCA & 60 \\
\hline & $\mathrm{RP}$ & GGGCAGACGGCCAGTTC & \\
\hline \multirow[t]{2}{*}{ Rpl19 } & FP & CCGCAGCCATGAGTATGCT & 60 \\
\hline & $\mathrm{RP}$ & CGCAGCGGAGGACACTAGA & \\
\hline
\end{tabular}

and then frozen in liquid nitrogen. Sections at $10-\mu \mathrm{m}$ thickness were cut horizontally and stored at $-80 \mathrm{C}$ until use.

The sections were completely dried, processed using $0.5 \mu \mathrm{g} / \mathrm{ml}$ proteinase K (Nacalai Tesque, Kyoto, Japan) at $37 \mathrm{C}$ for $10 \mathrm{~min}$, treated at room temperature with 4\% paraformaldehyde in PBS for $10 \mathrm{~min}$ and $0.2 \%$ glycine in PBS for $20 \mathrm{~min}$, and then acetylated with $0.15 \mathrm{M}$ acetic anhydride in $0.1 \mathrm{M}$ triethanolamine for $10 \mathrm{~min}$. The sections were then prehybridized in $4 \times$ SSPE, $1 \times$ Denhardt's solution, $10 \%$ dextran sulfate, $50 \%$ deionized formamide, and yeast tRNA $(50 \mu \mathrm{g} / \mathrm{slide})$ at room temperature for $30 \mathrm{~min}$. The sections were then hybridized with DIG-labeled antisense or sense Runx3 riboprobes $(50 \mathrm{ng} / \mathrm{slide})$ in prehybridization solution, and were placed in a moist chamber, overnight at $70 \mathrm{C}$.

After hybridization for $16 \mathrm{~h}$, the uterine tissue slides were washed in $1 \times \mathrm{SSC}$ in $30 \%$ formamide at room temperature for $10 \mathrm{~min}$, at 53 $\mathrm{C}$ for $15 \mathrm{~min}$ and then in $0.5 \times \mathrm{SSC}$ in $30 \%$ formamide at $53 \mathrm{C}$ for $15 \mathrm{~min}$. Next, the sections were blocked in $0.5 \%$ Blocking Reagent (Roche Diagnostics) dissolved in TBS-T at room temperature for 30 min, and then were incubated with anti-DIG-alkaline phosphatase (AP), Fab fragments (Roche Diagnostics) in blocking solution overnight at $4 \mathrm{C}$.

For color development, the slides were washed in TBS-T and AP buffer containing $0.1 \mathrm{M} \mathrm{NaCl}, 0.05 \mathrm{M} \mathrm{MgCl}_{2}, 0.1 \mathrm{M}$ Tris- $\mathrm{HCl}$ (pH9.5), $0.1 \%$ Tween-20, $2 \mathrm{mM}$ (-)-tetramisole hydrochloride (Sigma-Aldrich). Hybridization signals were detected in AP buffer containing $35 \mu \mathrm{g} /$ $\mathrm{ml}$ nitro blue tetrazolium chloride (Wako Pure Chemical Industries, Osaka, Japan) and $17.5 \mu \mathrm{g} / \mathrm{ml}$ 5-bromo-4-chloro-3'-indoylphosphate p-toluidine salt (Wako Pure Chemical Industries).
Morphological observation

Run $\times 3^{---}$and wt mice were sacrificed under $\mathrm{CO}_{2}$ anesthesia, and their uteri were fixed in Bouin's fixative, dehydrated and embedded in paraffin. Seven-micrometer-thick sections were cut and stained with hematoxylin and eosin.

Quantitative real-time RT-PCR analysis

Quantitative real-time PCR was conducted in a $15-\mu$ l final volume containing the following reagents: autoclaved water up to $15 \mu 1$, $1 \times$ SYBR Premix Ex Taq (Takara Bio, Otsu, Japan), $0.4 \mu \mathrm{M}$ each of forward and reverse primers, $1 \times \mathrm{ROX}$ Reference Dye and $1.5 \mu \mathrm{l}$ of cDNA appropriately diluted for each gene. A 7300 Fast Real-Time PCR System (Applied Biosystems) was used for PCR with the following conditions: $10 \mathrm{sec}$ at $95 \mathrm{C}$; 40 cycles of $95 \mathrm{C}$ for $5 \mathrm{sec}$ and $60 \mathrm{C}$ for $31 \mathrm{sec}$; $95 \mathrm{C}$ for $15 \mathrm{sec}, 60 \mathrm{C}$ for $1 \mathrm{~min}, 95 \mathrm{C}$ for $15 \mathrm{sec}$, and $60 \mathrm{C}$ for $15 \mathrm{sec}$. The primers are listed in Table 1. The relative expression levels of each sample were calculated based on the cycle threshold and growth curves. PCR amplification curves were evaluated by determining the fluorescence of the double-stranded DNA-specific dye SYBR Green in the test product vs. the amount in standardized PCR products. The expression level of each target mRNA was normalized to that of ribosomal protein L19 (Rpl19) mRNA.

Analysis of cell proliferation

DNA-synthesizing cells of endometrial epithelial cells were determined by bromodeoxyuridine (BrdU) incorporation using a Cell Proliferation ELISA, BrdU kit (Roche Diagnostics). Cultured uterine epithelial cells were treated with epidermal growth factor (EGF; $10 \mathrm{ng} / \mathrm{ml}), \mathrm{TGF} \alpha(10 \mathrm{ng} / \mathrm{ml})$ and TGF $\beta$ family proteins (1 $\mathrm{ng} / \mathrm{ml})$ for $12 \mathrm{~h}$ or IGF1 (100 $\mathrm{ng} / \mathrm{ml})$ for $24 \mathrm{~h}$. Four hours prior to measurement, BrdU was added to each well to a final concentration of $10 \mu \mathrm{M}$. The cells were fixed, and their DNA was denatured using the FixDenat supplied with the ELISA kit (Roche Diagnostics). Cells were incubated with anti-BrdU-POD at room temperature for $90 \mathrm{~min}$. Then, the cells were washed and added to tetramethylbenzidine as a substrate. The substrate reaction was stopped by adding $1 \mathrm{M}$ sulfuric acid. The absorbance of the samples was measured at a wavelength of $450 \mathrm{~nm}$ in a model 680 Microplate Reader (Bio-Rad Laboratories, Hercules, CA, USA).

\section{Statistical analysis}

Data are shown as the mean \pm standard error. Differences among groups were analyzed by analysis of variance followed by Tukey's test. Differences in the means between two groups were analyzed by the Student's $t$-test. Differences were considered significant at $\mathrm{P}<0.05$.

\section{Results}

Runx 3 mRNA and Runx 3 protein expressions in mouse uteri and ovaries

RT-PCR analysis of Runx 3 mRNA expression showed that Runx 3 mRNA was present in the uteri and ovaries of 8-week-old mice (Fig. 1A). Runx3 protein expression in the mouse uteri and ovaries was detected by Western blotting with an anti-Runx3 antibody (R3-1E10). The major band at $47 \mathrm{kDa}$ corresponded to Runx3 (calculated molecular weight 44,980) (Fig. 1B). 
A

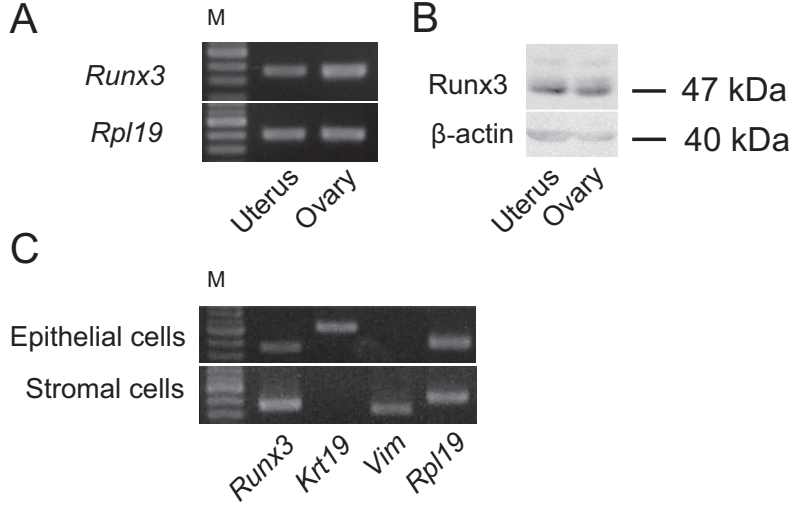

Fig. 1. Runx 3 expressions in the uterus and ovaries from 8-weekold mice. A: RT-PCR analysis of Runx 3 mRNA expression; Rpl19 mRNA expression was used as a control. M: molecular marker. B: Western blotting of Runx3 expression. An immunoreactive band $(47 \mathrm{kDa})$ was detected using an antiRunx3 antibody (R3-1E10). $\beta$-actin expression was used as a control. C: RT-PCR analysis of Runx3 mRNA expression in endometrial epithelial and stromal cells isolated from the uteri of immature mice. Krt19: keratin 19, a marker of epithelial cells. Vim: vimentin, a marker of stromal cells.

Endometrial epithelial and stromal cells were isolated from the uteri of immature mice, and were confirmed by detection of keratin or vimentin mRNA expression (Fig. 1C). Runx3 mRNA was detected in both cell types.

\section{In situ hybridization analysis of Runx $3 \mathrm{mRNA}$ expression in} mouse uteri

The expression of Runx 3 mRNA in the uteri of 8-week-old mice was examined using DIG-labeled riboprobes. The uteri comprised endometrial luminal epithelial and stromal cells, endometrial glandular epithelial cells, myometrial cells, and cells of the outer layers (Fig. 2A, D). Hybridization signals from DIG-labeled antisense riboprobes were localized in endometrial luminal epithelial cells, glandular epithelial cells, and stromal cells below the epithelial cell layer on the luminal side (Fig. 2B). There was no signal from the control sense riboprobe (Fig. 2C).

\section{Morphological observation of Runx $3^{-1-}$ mouse uterus}

The uteri of Run $x 3^{-/}$mice were smaller than those of wt mice. The endometrial layer and uterine glands of Run $x 3^{-/-}$mice were less developed than those of wt mice (Fig. 3), and the endometrial stromal layer was thinner.

Effect of E2 on estrogen receptor and growth factor $m R N A$ expressions in endometrial stromal cells of wt and Runx $3^{-1-}$ mice

To investigate the effect of $\mathrm{E} 2$ on the production of growth factors in the uterus of Run $\times 3^{-/}$mice, isolated endometrial stromal cells from immature mice were cultured, and treated with E2 $\left(10^{-8} \mathrm{M}\right)$ for 2 and 12 h. Esr 1, Igf1, Igfbp3, Egf, Tgfa, Tgfb1, Tgfb2 and Tgfb3 mRNA levels were analyzed by quantitative real-time PCR (Fig. 4).

Esr 1: Esr 1 mRNA levels in Runx $3^{-/-}$stromal cells of the control

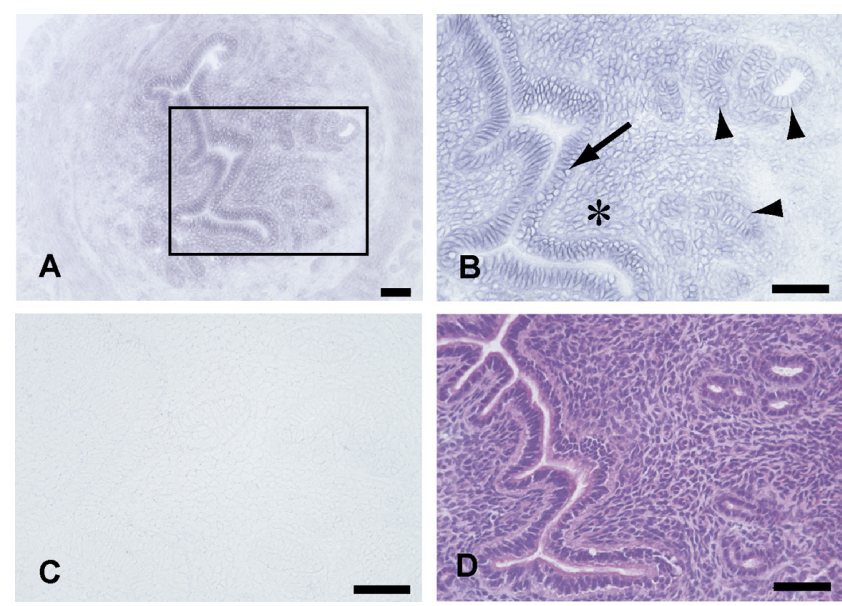

Fig. 2. In situ hybridization analysis of Runx 3 mRNA in mouse uteri. Uterine sections were obtained from 8-week-old mice. A-C: In situ hybridization with DIG-labeled Runx3 antisense (A, B) and sense (C) RNA probes. The boxed area in A corresponds to the area shown in B. Runx 3 mRNA signals were detected in endometrial luminal epithelial cells (arrow), glandular epithelial cells (arrowheads), and stromal cells of the luminal side (asterisk). No signals were detected with the sense probe (C). D: Hematoxylin and eosin-stained section. Bars $=50 \mu \mathrm{m}$.

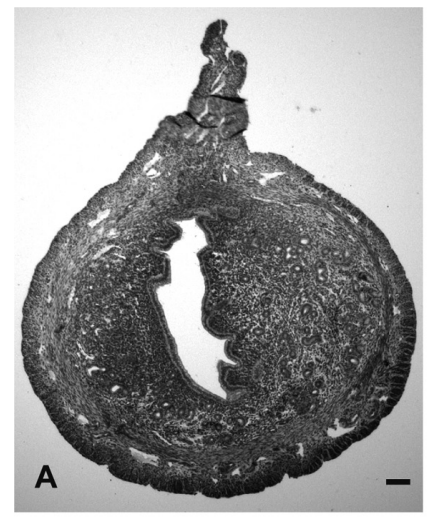

B
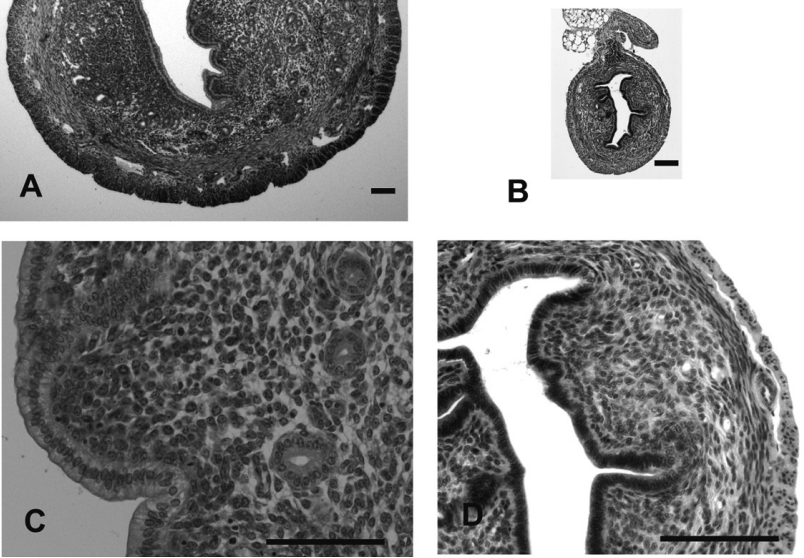

Fig. 3. Morphological analysis of the uteri of $R u n \times 3^{-/-}$mice. Representative cross sections of uteri from 8-week-old wt (A, C) and $\operatorname{Run} 3^{--}$(B, D) mice are shown. Bars $=100 \mu \mathrm{m}$.

group were lower than in wt stromal cells. E2 decreased Esr1 mRNA levels in wt and Runx $3^{-/-}$stromal cells at $12 \mathrm{~h}$.

Igf1: E2 tended to increase Igfl mRNA levels at $2 \mathrm{~h}$, but statistical significant differences were not detected in wt and Run $\times 3^{-1-}$ stromal cells. E2 increased IgfI mRNA levels at $12 \mathrm{~h}$ in Runx $3^{-/-}$stromal cells. 

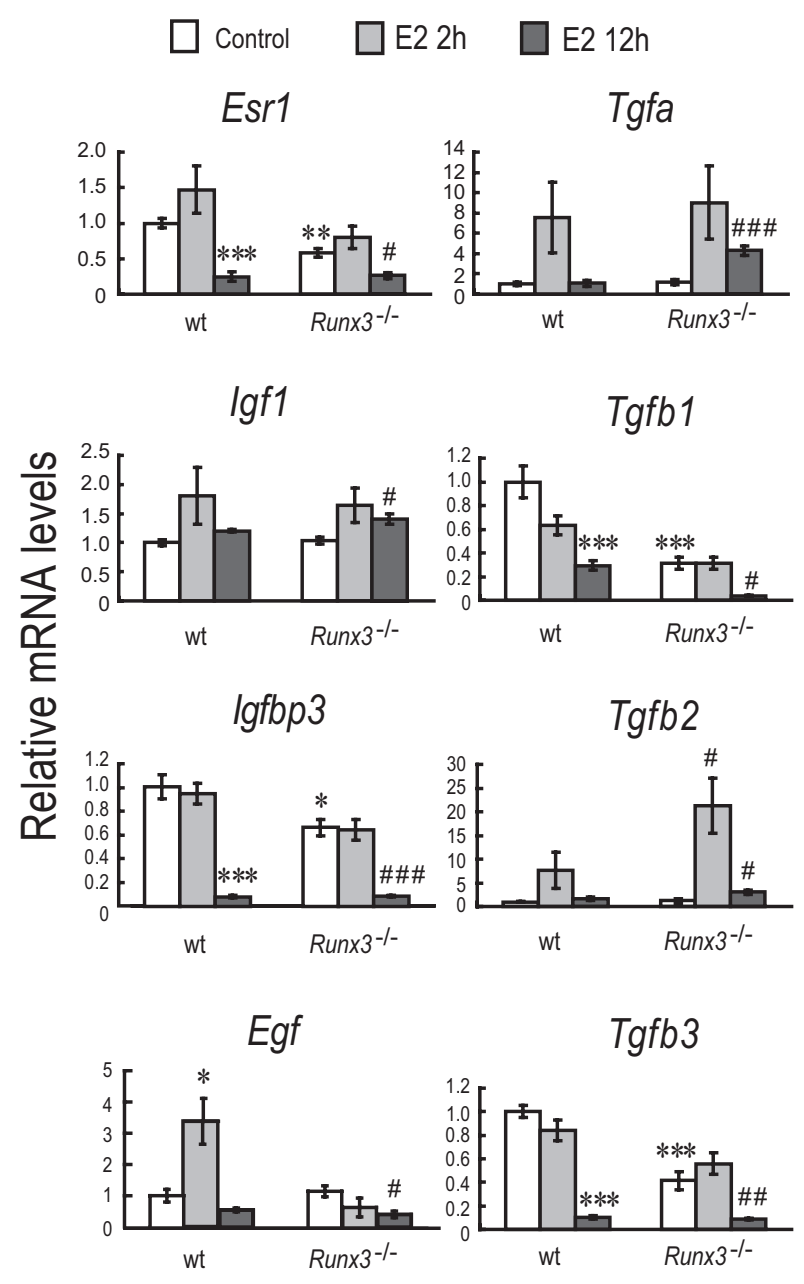

Fig. 4. Effect of $\mathrm{E} 2$ on $\mathrm{ER} \alpha$ and growth factor mRNA expression in the endometrial stromal cells of wt and Runx $3^{-1-}$ mice. Endometrial stromal cells were treated with E2 $\left(10^{-8}\right.$ M). Cells were collected at 2 and $12 \mathrm{~h}$ after the hormone treatment. Real-time RT-PCR was performed for quantitative analysis of Esr1, Igf1, Igfbp3, Egf, Tgfa, Tgfb1, Tgfb2 and $T g f b 3$ mRNA expression. The amount of each mRNA in wt and Runx $3^{-/-}$mice was normalized against that of Rpl19 mRNA. Each group consisted of triplicate wells, and the data are expressed as the mean \pm standard error. ${ }^{*} \mathrm{P}<0.05$, ** $\mathrm{P}<0.01, * * * \mathrm{P}<0.001$, significantly different from control of wt mice. \# $\mathrm{P}<0.05$; \#\# $\mathrm{P}<0.01$; \#\# $\mathrm{P}<0.001$; significantly different from the control.

Igfbp3: Igfbp3 mRNA levels in Runx $3^{-/-}$stromal cells of the control group were lower than in wt stromal cells. E2 decreased Igfbp 3 mRNA levels at $12 \mathrm{~h}$ in wt and Run $\times 3^{-1-}$ stromal cells.

$E g f:$ E2 increased $E g f$ mRNA levels at $2 \mathrm{~h}$ in wt stromal cells, but not in Runx $3^{-/-}$stromal cells.

$T g f a$ : E2 increased $T g f a$ mRNA levels at $2 \mathrm{~h}$ in wt and Runx $3^{-/-}$ stromal cells, but statistically significant differences were not obtained, while high $T g f a$ mRNA levels remained at $12 \mathrm{~h}$ in $R u n \times 3^{-/-}$stromal cells.

Tgfb1: Tgfb1 mRNA levels in Runx $3^{-/-}$stromal cells were lower than in wt stromal cells. E2 decreased $T g f b 1$ mRNA levels at $12 \mathrm{~h}$ in wt and Run $\times 3^{-/-}$stromal cells.
A
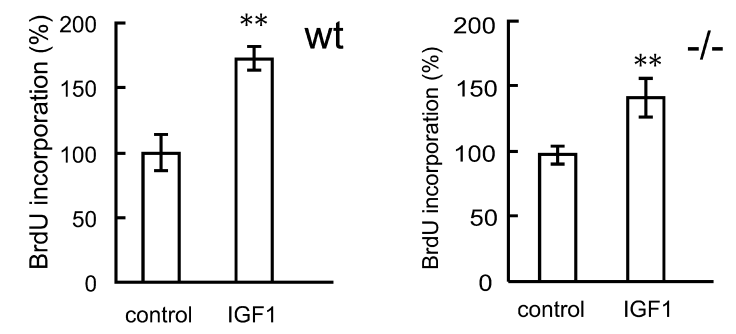

B

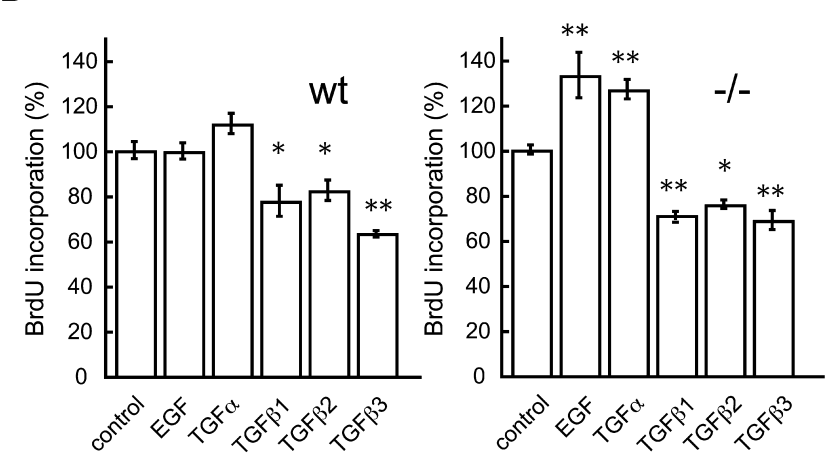

Fig. 5. Effect of growth factors on DNA synthesis in cultured endometrial epithelial cells. The endometrial epithelial cells were treated with IGF1 for $48 \mathrm{~h}$ (A) or with EGF, TGF $\alpha$, TGF $\beta 1$, TGF $\beta 2$ or TGF 33 for $12 \mathrm{~h}$ (B). DNA synthesis was measured by BrdU incorporation. The results are expressed as a percentage taking the BrdU incorporation of the controls as $100 \%$. ${ }^{*} \mathrm{P}<0.05$; $* * \mathrm{P}<0.01$; significantly different from the control.

Tgfb2: E2 increased Tgfb2 mRNA levels at 2 and $12 \mathrm{~h}$ in $R u n x 3^{-/-}$ stromal cells.

Tgfb3: $T g f b 3$ mRNA levels in Run $x 3^{-/-}$stromal cells were lower than those in wt stromal cells. E2 decreased $T g f b 3$ mRNA levels in wt and Run $\times 3^{-/-}$stromal cells.

\section{Effects of growth factors on proliferation of endometrial epithelial and stromal cells in Run $x 3^{-1-}$ mice and wt mice}

We examined the effect of growth factors on proliferation of endometrial epithelial cells by analyzing the BrdU uptake into the nucleus.

Endometrial epithelial cells: In endometrial epithelial cells of wt and Runx $3^{-/-}$mice, IGF1 treatment significantly increased BrdU incorporation (Fig. 5A), whereas TGF $\beta 1$, TGF $\beta 2$ and TGF $\beta 3$ significantly decreased BrdU incorporation (Fig. 5B). EGF and $\mathrm{TGF} \alpha$ increased BrdU incorporation in endometrial epithelial cells of Run $x 3^{-1-}$ mice only.

Endometrial stromal cells: IGF1 treatment did not change BrdU incorporation in the stromal cells of wt mice but did increase it in the stromal cells of Run $x 3^{--}$mice (Fig. 6A). On the other hand, EGF, TGF $\alpha$ and the TGF $\beta$ family proteins increased BrdU incorporation in stromal cells of wt and Runx $3^{-/-}$mice (Fig. 6B). 


\section{Discussion}

Transcription factor Runx3-knockout mice are infertile, and their uteri are atrophied, suggesting that Runx 3 is involved in the regulation of reproductive function. Accordingly, we demonstrated the presence of Runx 3 mRNA and protein in the mouse uterus. By in situ hybridization, we detected Runx 3 mRNA in the endometrial luminal epithelial cells, glandular epithelial cells, and stromal cells below the epithelial cell layer on the luminal side. RT-PCR analysis confirmed that Runx 3 mRNA was expressed in the endometrial epithelial and stromal cells. Runx 3 mRNA expression within the mouse endometrium strongly suggests that Runx3 plays important roles in the regulation of uterine functions. In addition, $T g f b l$ and $T g f b 3$ mRNA expression, and E2-induced synthesis of EGF and TGF $\beta 2$ was altered in the endometrial stromal cells of Run $x 3^{-/-}$mice. These alterations may be involved in the atrophy of uteri and loss of estrogen-induced proliferation of endometrial epithelial cells in Run $x 3^{-/-}$mice.

Morphological observations showed that the endometrial layer and uterine glands of Runx $3^{--1}$ mice were less developed than those of wt mice. The growth of endometrial epithelial and stromal cells is regulated by estrogen and progestin [3]. The ovaries of Run $x 3^{-/-}$mice contained fewer antral follicles, which mainly secrete estrogen, and no corpora lutea, which secrete progestin, suggesting reduced secretion of estrogen and progestin. Recently, we found that E2 did not promote the proliferation of the endometrial epithelial cells in Run $\times 3^{--}$mice [4]. This indicates that the growth and function of endometrial cells were retarded in $R u n \times 3^{--}$mice, and that the atrophy of $R u n x 3^{-/}$mouse uteri was not only because of reduced estrogen and progestin secretion but also because of a diminished response of endometrial epithelial cells to estrogen in terms of cell proliferation. Thus, it is highly probable that Runx3 in endometrial cells is involved in the regulation of their proliferation.

ER $\alpha$ expression in the uterus of Runx $3^{-/-}$mice was not altered, because uterine Esrl mRNA levels did not differ between wt and Run $x 3^{-/-}$mice [4]. However, Esr 1 mRNA levels in endometrial stromal cells of Run $x 3^{--}$mice were significantly lower than those in wt mice. Hence, ER $\alpha$ expression in endometrial stromal cells may be reduced by Runx3 knockout, although we did not specifically determine ER $\alpha$ levels. Esr 1 mRNA expression was down-regulated by E2 treatment in both endometrial stromal cells of both wt and Run $x 3^{-1-}$ mice. Thus, it is still not clear whether Runx3 is involved in the regulation of ER expression.

The proliferation of endometrial epithelial and stromal cells is regulated by growth factors produced in endometrial cells $[6,7,13$, 19-21]. Among the growth factors produced in endometrial cells, IGF1 and the EGF family members stimulate proliferation and the TGF $\beta$ family members inhibited proliferation of endometrial epithelial cells $[8,9,11-13,22,23]$. On the other hand, IGF1, the EGF family members and the TGF $\beta$ family members stimulate DNA synthesis of endometrial stromal cells $[5,10]$. In the present study, $T g f b 1$ and $T g f b 3$ mRNA expression in endometrial stromal cells of Run $x 3^{-/-}$mice was reduced compared with that in control wt mice, implying that the decrease in synthesis of these growth factors in Run $x 3^{3^{--}}$mouse uteri was probably associated with retarded growth of $R u n \times 3^{-/}$mouse uteri. Runx 3 may be involved in the proliferation
A
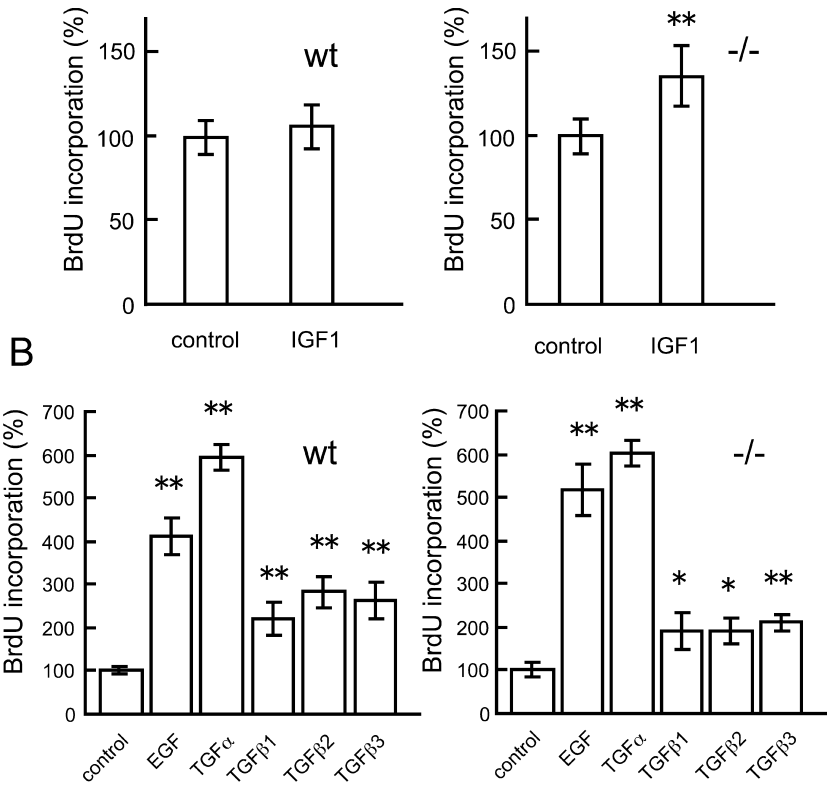

Fig. 6. Effect of growth factors on DNA synthesis in cultured endometrial stromal cells. The endometrial stromal cells were treated with IGF1 for $48 \mathrm{~h}$ (A), or with EGF, TGF $\alpha$, TGF $\beta 1$, TGF $\beta 2$, or TGF $\beta 3$ for $12 \mathrm{~h}$ (B). DNA synthesis was measured by BrdU incorporation. The results were expressed as a percentage taking the BrdU incorporation of controls as $100 \%$. $* \mathrm{P}<0.05 ; * * \mathrm{P}<0.01$; significantly different from the control.

of endometrial cells through the production of growth factors.

The production of growth factors in endometrial stromal cells is regulated by estrogen $[6,24-26]$. The TGF $\beta$ family growth factors control cell proliferation [23]. The TGF $\beta$ family growth factors inhibited proliferation of endometrial epithelial cells and stimulated that of endometrial stromal cells. The EGF family growth factors stimulate both endometrial epithelial and stromal cells. E2 treatment resulted in an increase in $T g f b 2$ mRNA expression at $2 \mathrm{~h}$ in endometrial stromal cells of Runx $3^{-1-}$ mice, but did not in those of wild-type mice. On the other hand, an E2-induced increase in Egf mRNA at $2 \mathrm{~h}$ was detected in endometrial stromal cells of wt mice, but not in those of Run $x 3^{-/-}$mice. Therefore, it is probable that the failure of E2-induced proliferation of endometrial epithelial cells in Run $x 3^{-/-}$mice occurs because of the enhanced release of TGF $\beta 2$ induced by estrogen and the reduced release of EGF.

IGF1 promotes the proliferation of endometrial epithelial and stromal cells [8-10, 27]. Moreover, the expression of Igfl is regulated by estrogen [24, 28-30]. IGF binding protein-3 (IGFBP-3) is known to inhibit IGF1 action and extend its half-life by binding to it [31, 32], and is considered to regulate endometrial cell proliferation [33]. Therefore, we examined the E2-induced mRNA expression of IgfI and $I g f b p 3$. E2 treatment appeared to increase $I g f 1$ mRNA levels at $2 \mathrm{~h}$ in endometrial stromal cells of both the wt and Run $\times 3^{--}$uterus, although a statistically significant difference was not obtained because of large variations of mRNA levels of E2-treated endometrial cells. E2 treatment inhibited $\operatorname{Ig} f b p 3$ mRNA expression at $12 \mathrm{~h}$ in endometrial stromal cells of both wt and Run $x 3^{-/-}$uterus. This may 
suggest that Runx3 is not involved in IGF1-mediated regulation of endometrial cell proliferation.

We assessed the proliferation of endometrial epithelial and stromal cells by detection BrdU incorporation into the nucleus. In endometrial epithelial cells, IGF1 increased BrdU uptake in wt and Run $x 3^{-/}$mice, but TGF $\beta 1$, TGF $\beta 2$ and TGF $\beta 3$ decreased it. EGF and TGF $\alpha$ increased BrdU uptake in the endometrial epithelial cells of Runx $3^{-/}$mice only. The endometrial stromal cells of $R u n \times 3^{-/}$mice responded to TGF $\beta 1$, TGF $\beta 2$ and TGF $\beta 3$, resulting in increases in DNA synthesis, while IGF1 increased BrdU uptake in the endometrial cells of Run $x 3^{-/-}$mice. The discrepancy between the present study and previous studies $[10,12]$ may be due to differences in the culture conditions and growth factor treatments employed. However, these findings imply that endometrial epithelial and stromal cells of Runx $3^{-/-}$mice had the ability to respond to these growth factors like those of wt mice.

In conclusion, we detected local expression of Runx 3 mRNA in the endometrial luminal epithelial cells, glandular epithelial cells, and stromal cells below the epithelial cell layer on the luminal side. $T g f b 1$ and $T g f b 3$ mRNA expression in endometrial stromal cells of Run $\times 3^{-/-}$mice was reduced, probably leading to hypoplasia of the endometrium. E2 increased $T g f b 2$ mRNA expression but not $E g f$ mRNA expression in the endometrial stromal cells of $R u n x 3^{-/}$mice. It is possible that these alterations caused by Runx 3 deletion are associated with loss of E2-dependent endometrial epithelial cell proliferation in Runx $3^{-1-}$ mice. Runx3 is likely a regulatory factor responsible for endometrial growth.

\section{Acknowledgments}

We thank Dr K Ito, Graduate School of Biomedical Sciences, Nagasaki University, for his kind advice. This study was supported in part by a Grant-in-Aid for Scientific Research from the Japan Society for the Promotion of Science to S Takahashi.

\section{References}

1. Ito Y. Molecular basis of tissue-specific gene expression mediated by the runt domain transcription factor PEBP2/CBF. Genes Cells 1999; 4: 685-696. [Medline] [CrossRef]

2. Hanai J, Chen LF, Kanno T, Ohtani-Fujita N, Kim WY, Guo WH, Imamura T, Ishidou Y, Fukuchi M, Shi MJ, Stavnezer J, Kawabata M, Miyazono K, Ito Y. Interaction and functional cooperation of PEBP2/CBF with Smads. Synergistic induction of the immunoglobulin germline C $\alpha$ promoter. J Biol Chem 1999; 274: 31577-31582. [Medline] [CrossRef]

3. Huet-Hudson YM, Andrews GK, Dey SK. Cell type-specific localization of c-myc protein in the mouse uterus: modulation by steroid hormones and analysis of the periimplantation period. Endocrinology 1989; 125: 1683-1690. [Medline] [CrossRef]

4. Sakuma A, Fukamachi H, Ito K, Ito Y, Takeuchi S, Takahashi S. Loss of Runx3 affects ovulation and estrogen-induced endometrial cell proliferation in female mice. Mol Reprod Dev 2008; 75: 1653-1661. [Medline] [CrossRef]

5. Beck CA, Garner CW. Stimulation of DNA synthesis in rat uterine cells by growth factors and uterine extracts. Mol Cell Endocrinol 1992; 84: 109-118. [Medline] [CrossRef]

6. Takahashi T, Eitzman B, Bossert NL, Walmer D, Sparrow K, Flanders KC, McLachlan J, Nelson KG. Transforming growth factors $\beta 1, \beta 2$, and $\beta 3$ messenger RNA and protein expression in mouse uterus and vagina during estrogen-induced growth: a comparison to other estrogen-regulated genes. Cell Growth Differ 1994; 5: 919-935. [Medline]

7. Cooke PS, Buchanan DL, Young P, Setiawan Y, Brody J, Korach KS, Taylor J, Lubahn DB, Cunha GR. Stromal estrogen receptors mediate mitogenic effects of estradiol on uterine epithelium. Proc Natl Acad Sci USA 1997; 94: 6535-6540. [Medline] [CrossRef]

8. Shiraga M, Takahashi S, Miyake T, Takeuchi S, Fukamachi H. Insulin-like growth factor-I stimulates proliferation of mouse uterine epithelial cells in primary culture. Proc Soc Exp Biol Med 1997; 215: 412-417. [Medline]
9. Sato T, Wang G, Hardy MP, Kurita T, Cunha GR, Cooke PS. Role of systemic and local IGF-I in the effects of estrogen on growth and epithelial proliferation of mouse uterus. Endocrinology 2002; 143: 2673-2679. [Medline] [CrossRef]

10. Inoue A, Takeuchi S, Takahashi S. Insulin-like growth factor-I stimulated DNA replication in mouse endometrial stromal cells. J Reprod Dev 2005; 51: 305-313. [Medline] [CrossRef]

11. Tomooka Y, DiAugustine RP, McLachlan JA. Proliferation of mouse uterine epithelial cells in vitro. Endocrinology 1986; 118: 1011-1018. [Medline] [CrossRef]

12. Shiraga M, Komatsu N, Teshigawara K, Okada A, Takeuchi S, Fukamachi H, Takahashi S. Epidermal growth factor stimulates proliferation of mouse uterine epithelial cells in primary culture. Zool Sci 2000; 17: 661-666. [Medline] [CrossRef]

13. Komatsu N, Maekawa T, Takeuchi S, Takahashi S. Epidermal growth factor and transforming growth factor- $\alpha$ stimulate the proliferation of mouse uterine stromal cells. Zool Sci 2003; 20: 639-645. [Medline] [CrossRef]

14. Tamada H, McMaster MT, Flanders KC, Andrews GK, Dey SK. Cell type-specific expression of transforming growth factor- $\beta 1$ in the mouse uterus during the periimplantation period. Mol Endocrinol 1990; 4: 965-972. [Medline] [CrossRef]

15. Li QL, Ito K, Sakakura C, Fukamachi H, Inoue K, Chi XZ, Lee KY, Nomura S, Lee CW, Han SB, Kim HM, Kim WJ, Yamamoto H, Yamashita N, Yano T, Ikeda T, Itohara S, Inazawa J, Abe T, Hagiwara A, Yamagishi H, Ooe A, Kaneda A, Sugimura T, Ushijima T, Bae SC, Ito Y. Causal relationship between the loss of RUNX3 expression and gastric cancer. Cell 2002; 109: 113-124. [Medline] [CrossRef]

16. Yamamoto H, Ito K, Kawai M, Murakami Y, Bessho K, Ito Y. Runx3 expression during mouse tongue and palate development. Anat Rec A Discov Mol Cell Evol Biol 2006; 288: 695-699. [Medline]

17. Ross AK, Nelson KG, Sakai Y, Fukamachi H, Burroughs CD, McLachlan JA. Isolation and culture of mouse uterine epithelial and stromal cells. In: Heindel JJ, Chapin RE (eds.), Methods in Toxicology. San Diego: Academic Press; 1993: 371-385.

18. Murakami Y, Otsuki M, Kusumoto K, Takeuchi S, Takahashi S. Estrogen inhibits interleukin-18 mRNA expression in the mouse uterus. J Reprod Dev 2005; 51: 639-647. [Medline] [CrossRef]

19. Bigsby RM, Cunha GR. Estrogen stimulation of deoxyribonucleic acid synthesis in uterine epithelial cells which lack estrogen receptors. Endocrinology 1986; 119: 390-396. [Medline] [CrossRef]

20. Astrahantseff KN, Morris JE. Estradiol-17 $\beta$ stimulates proliferation of uterine epithelial cells cultured with stromal cells but not cultured separately. In Vitro Cell Dev Biol Anim 1994; 30A: 769-776. [Medline] [CrossRef]

21. Pierro E, Minici F, Alesiani O, Miceli F, Proto C, Screpanti I, Mancuso S, Lanzone A. Stromal-epithelial interactions modulate estrogen responsiveness in normal human endometrium. Biol Reprod 2001; 64: 831-838. [Medline] [CrossRef]

22. Hu PP, Datto MB, Wang XF. Molecular mechanisms of transforming growth factor- $\beta$ signaling. Endocr Rev 1998; 19: 349-363. [Medline] [CrossRef]

23. Huang SS, Huang JS. TGF- $\beta$ control of cell proliferation. $J$ Cell Biochem 2005; 96 447-462. [Medline] [CrossRef]

24. Murphy LJ, Murphy LC, Friesen HG. Estrogen induces insulin-like growth factor-I expression in the rat uterus. Mol Endocrinol 1987; 1: 445-450. [Medline] [CrossRef]

25. Godkin JD, Dore JJ. Transforming growth factor $\beta$ and the endometrium. Rev Reprod 1998; 3: 1-6. [Medline] [CrossRef]

26. Ohtsuki T, Otsuki M, Murakami Y, Maekawa T, Yamamoto T, Akasaka K, Takeuchi S, Takahashi S. Organ-specific and age-dependent expression of insulin-like growth factor-I (IGF-I) mRNA variants: IGF-IA and IB mRNAs in the mouse. Zool Sci 2005; 22: 1011-1021. [Medline] [CrossRef]

27. Zhu L, Pollard JW. Estradiol-17ß regulates mouse uterine epithelial cell proliferation through insulin-like growth factor 1 signaling. Proc Natl Acad Sci USA 2007; 104 15847-15851. [Medline] [CrossRef]

28. Ghahary A, Chakrabarti S, Murphy LJ. Localization of the sites of synthesis and action of insulin-like growth factor-I in the rat uterus. Mol Endocrinol 1990; 4: 191-195. [Medline] [CrossRef]

29. Kapur S, Tamada H, Dey SK, Andrews GK. Expression of insulin-like growth factor-I (IGF-I) and its receptor in the peri-implantation mouse uterus, and cell-specific regulation of IGF-I gene expression by estradiol and progesterone. Biol Reprod 1992; 46: 208-219. [Medline] [CrossRef]

30. Ohtsuki T, Otsuki M, Murakami Y, Hirata K, Takeuchi S, Takahashi S. Alternative leader-exon usage in mouse IGF-I mRNA variants: class 1 and class 2 IGF-I mRNAs. Zool Sci 2007; 24: 241-247. [Medline] [CrossRef]

31. Hwa V, Oh Y, Rosenfeld RG. The insulin-like growth factor-binding protein (IGFBP) superfamily. Endocr Rev 1999; 20: 761-787. [Medline]

32. Duan C, Xu Q. Roles of insulin-like growth factor (IGF) binding proteins in regulating IGF actions. Gen Comp Endocrinol 2005; 142: 44-52. [Medline] [CrossRef]

33. Maekawa T, Takeuchi S, Kanayama M, Takahashi S. Estradiol, progesterone, and transforming growth factor $\alpha$ regulate insulin-like growth factor binding protein-3 (IGFBP3) expression in mouse endometrial cells. Zool Sci 2009; 26: 131-138. [Medline] [CrossRef] 